Egyptian Journal of Aquatic Biology \& Fisheries

Zoology Department, Faculty of Science,

Ain Shams University, Cairo, Egypt.

ISSN $1110-6131$

Vol. 23(4): 563 - 575 (2019)

www.ejabf.journals.ekb.eg

\title{
Application of DNA barcoding for identifying potential biotechnological candidate organisms from the River Nile, Egypt.
}

\author{
Khaled Mohammed-Geba, Mansour Galal*, Gamalat Y Osman and \\ Mona M Soliman. \\ Department of Zoology, Faculty of Sciences, Menoufia University, Shebin El-Kom, \\ Menoufia Governorate, Egypt. \\ Corresponding Author: mansour_galal_eg@yahoo.com.
}

\section{ARTICLE INFO \\ Article History: \\ Received: Sept. 21, 2019 \\ Accepted: Oct. 28, 2019 \\ Online: Nov. 2019}

\section{Keywords:}

Ciliated Protozoa

DNA barcoding

River Nile

Euplotes woodurffi

Halteria grandinella

\section{ABSTRACT}

Ciliated protozoa play many fundamental roles in the aquatic environments where they thrive. They mediate the microbial loop of the universal food web, control the surrounding organisms, and act as biomarkers for water quality, beside some capability for the production of bioactive compounds. Identification of different ciliate species is chiefly based on morphological taxonomy. In order to develop molecular tools that facilitate the exploration of freshwater Nile ciliates, a direct, 18srDNAbased PCR assay was tuned up. This assay was tested for DNA-barcoding of some species that prevail the Nile in Mansoura City in the North of Egypt. The resulting sequences were applied to design new species-specific PCR assays for detection of density of these ciliates in River Nile. Using both newly-designed primers and assays, the top identified species were Euplotes woodurffi, Halteria grandinella, and Coleps hirtus. The species-specific primers produced variable-sized PCR amplicons, with densities that were at least correlated by $95 \%$ with the real species count in the riverine water. The newly designed molecular tools are expected to facilitate the exploration and quantification of those species in different aquatic habitats where they exist, adding a major contribution to future efforts for exploiting them as resources for blue biotechnology.

\section{INTRODUCTION}

Ciliates are one of the most abundant taxa in the biosphere, representing key rate-controllers for sympatric bacteria, algae, and other protist populations. They also form a key part of the microbial loop of the universal food web, ultimately affecting its top level, viz. mammals including human (Corliss, 2002). Directly in relation to human benefits, they are gaining an increasing attention as promising experimental models, due to their short-time life cycles, rapid population resilience time, relative ease in laboratory culture, and a cosmopolitan distribution in almost all aquatic habitats on earth (Gutiérrez, et al., 2008). Even there are some recent studies that assessed the role of their pheromones and secondary metabolites as potential anticancer derivatives (Catalani et al., 2016). They have been elucidated as biomarkers for improved environmental quality, such as in the soil (Abraham et al., 2019). Moreover, some species actively reduce bacterial flocs and increase ammonia removal from activated sludge, leading to a long-term enhancement of sewage-treatment 
through activated sludge (Walczyńska et al., 2018). Also, they are key aquatic biosensors towards heavy metals due to the absence of a rigid cell wall, exhibiting in many cases the loss in cells' morphological integrity; roundness, intracellular vacuolization, morphological deformities and cellular rupture (Pudpong and Chantangsi, 2015 and Madoni and Romeo, 2006; Somasundaram et al., 2018). Even ciliates' superoxide dismutase exhibited clear heavy metal concentrations-dependent activities (Toteja et al., 2017).Freshwater ciliates contribute much to the environmental bioremediation from the heavy metals (Abraham et al., 2017). Ciliates also play a key role in water purification systems (Debastiani et al., 2016 and Radhakrishnan and Jayaprakas, 2015).

The early works on ciliate's taxonomy solely based on living morphology (Kahl; 1932 and Müller, 1786), then silver staining (Curds, 1975). However, with the advent of the molecular taxonomy era, there is a clearly increasing number of works that use molecular information to define species (Alekperov et al., 2006; Chen et al., 2013; Schwarz and Stoeck 2007; Schwarz et al., 2007; Syberg-Olsen et al., 2016; Zhao et al., 2018). Yet, still the classification of microbial eukaryotes using DNA barcoding and molecular phylogenies is hindered by the difficulty of isolating specific species, and it kept almost restricted to those that are easily cultured in the laboratory. Studies on the 18srDNA, also termed the small ribosomal subunit SSU rDNA, exhibited that this gene in ciliates have a high level of interspecific sequence variability upon its amplification by Polymerase chain reaction (PCR) and sequencing. Therefore, it gained a specific popularity as an important tool for ciliates' barcoding, phylogenies and other taxonomy-based analyses (Wang et al., 2017). It could be successfully applied to identify the seasonality of planktonic freshwater ciliates, the diversity of microbial communities hosted by some plants and colonizing some specific coastal systems like mangroves, systematic positioning of some ciliates species, as well as surveilling some ciliate species related to biomonitoring and ecological impacts-assessment of aquaculture of key fish species (Grimonprez et al., 2018; Yan et al., 2018; Forster et al., 2019; Grothjan and Young, 2019; Pitsch et al., 2019). Still DNA barcoding for free living ciliates a poorly researched discipline, despite the very well-known importance of this group in potable and waste water treatment (Galal et al., 2011; Galal, 2013 ).

The current work aims to: i) identify, at the molecular level, the most abundant River Nile ciliates, especially those having roles in environmental biotechnology; ii) provide a phylogenetic and DNA-barcoding-based evidences for their accurate species designation; and iii) develop different DNA barcoding primers based on their sequences to provide the possibility of their detection in water through PCR and QPCR.

\section{MATERIALS AND METHODS}

\section{Sampling and samples preservation}

Freshwater samples were collected from River Nile at Mansoura city Dakhleyia province, North Egypt (in front of EL-Sharq station for water treatment). The samples were transferred to the Lab of Molecular Genetics and Biotechnology in the Faculty of Science of Menoufia University (Shebin El-Kom City, Egypt). The samples were subjected to a rapid microscopic examination for identification of different kinds of ciliates according to Patterson and Hedley (1992). 


\section{Isolating Nile Ciliates}

Singular cells from the most abundant ciliates were collected manually using a $10 \mu \mathrm{L}$ micropipette, and each was placed in a single, $0.2 \mathrm{~mL}$ tube. Each cell of the selected species; Euplotes (Spirotrichea), Halteria (Oligotrichea), and Coleps (Prorodontida); was placed in $2 \mu \mathrm{L}$ of deionized water and then stored in a $-20{ }^{\circ} \mathrm{C}$ freezer until running the $18 \mathrm{srDNA}$-based PCR. This was carried out in triplicates for each species. At the same time, the rest of cells were sorted and placed in tubes containing only either of the three species, and stored in the $-20{ }^{\circ} \mathrm{C}$ deep freezer until subsequent genetic analyses.

\section{8srDNA primers design}

18srDNA sequences of many species belonging to the species that are mostly abundant in the area of study were retrieved from the GenBank database, for example E. euryhalinus (accession number MG994991.1), E. woodruffi (acc. No. MG994981.1), E. parawoodruffi (acc. No. AF452708.1), E. muscicola (acc. No. MH795290.1), E. harpa (acc. No. KX138651.1), Levicoleps biwae (acc. No. KT0726321), C. hirtus (acc. No. KF1772781.1), Uncultured Halteria sample (acc. No. GU067995.1) and Halteria grandinella (acc. No. AY007444.1). These sequences were aligned using ClustalW algorithm (Thompson et al., 1994) integrated to Mega6 (Tamura et al., 2013). The sequences were then trimmed to obtain a final common zone of about 600 base pairs. A single sequence from each species was uploaded to primer3plus algorithm (http://primer3plus.com/cgi-bin/dev/primer3plus.cgi) in order to design a pair of primers with annealing temperature between $55-60{ }^{\circ} \mathrm{C}$, maximum repetitions of the same nucleotides less than 3, and expected amplicon size of $800 \mathrm{bp}$. Also, the primers were checked to assure the least self-complementation of bases in each given primer alone and between the two primers in the selected primer pairs (not exceeding 3 complementary bases adjacent to each other) for avoiding formation of hair-pin loops.

\section{PCR amplification for 18s ribosomal RNA gene}

A direct PCR was carried out for the isolated single ciliates' cells, using the newly designed, universal primer pairs (EupF- EupR) that flank the hypervariable barcode region in the 18 s ribosomal RNA gene. The amplification reactions were performed in a total volume of $25 \mu \mathrm{L}$. The reaction mixture consisted of $2 \mu \mathrm{L}$ of deionized $\mathrm{H}_{2} \mathrm{O}$ containing the single ciliate organism as a template DNA, $12.5 \mu \mathrm{L}$ of MyRedTaq $^{\mathrm{TM}}$ PCR Master mix (BIOLINE), $0.4 \mu \mathrm{M}$ of each primer, and $5 \mu \mathrm{g}$ of Bovine serum albumin (BSA). A blank sample containing only PCR reagents and deionized water was included with that PCR as a negative control. PCR amplifications were run in the thermal cycler Biometra (T-personal 48, Germany). The PCR protocol included an initial denaturation step at $95^{\circ} \mathrm{C}$ for $10 \mathrm{~min}$, followed by 40 cycles of 95 ${ }^{\circ} \mathrm{C}$ for $45 \mathrm{~s}, 55.9^{\circ} \mathrm{C}$ for $45 \mathrm{~s}, 72{ }^{\circ} \mathrm{C}$ for $1 \mathrm{~min}$, and a final extension of $72{ }^{\circ} \mathrm{C}$ for 10 min. PCR products were electrophoresed in a $1 \%$ agarose gel. with a $1 \mathrm{kbp}$ DNA ladder(Thermo Scientific Cat No. SM0314). After completion of the electrophoresis, the agarose gel was visualized using a UV- Transilluminator (Transilluminator Ti 1, Biometra, Germany). Accurate sized PCR products ( 800bp) were purified from the Gel using Mega quick-Spin ${ }^{\mathrm{TM}}$ plus Fragment DNA purification Kit (Intron Biotechnology, South Korea), then sent to Macrogen Inc. (Seol, South Korea) for conventional Sanger sequencing.

\section{Genetic and phylogenetic Sequences analyses}

The quality of the obtained sequences was manually checked using the freeware Chromas 6.2.5. Sequences were manually checked and corrected for nucleotide 
deletions/insertions whenever necessary. Each sequence was individually compared to GenBank database using basic local alignment search tool, BLAST (http:// blast.ncbi.nlm.nih.gov/Blast.cgi; Altschul et al., 1990). Sequences of different species of the same genera were retrieved from the GenBank database, aligned using CLUSTALW as before. The file was saved as .nxs one. Bayesian inference (BI) for phylogenetic relations among assessed species was carried out using MrBayes 3.2.1 (Ronquist et al., 2018), Four Markov Chains Monte Carlo (MCMC) chains were analyzed for 10 million (ngen=10,000,000) generations, saving a tree each 1,000 generations. The subsequent analysis started when the average standard deviation of split frequencies reached 0.002. Tracer 1.7 (Rambaut et al., 2018) was applied for calculating effective samples size and number of burn-ins. Tracer 1.7 exhibited that $25 \%$ of the saved trees are to be discarded as burn-ins. This information was transferred to MrBayes 3.2.1. for constructing the summarized tree, which was later opened also using FigTree v 1.3.1.

\section{Design, testing, and application of species-specific primers}

Design of specific primers for Coleps, Euplotes and Halteria followed the same procedure detailed in section 2.1 before, but based on the specific 18srDNA sequence obtained for each species using the 18srDNA universal primers designed. Another critical criteria that was considered for the design of species-specific 18srDNA primers is to provide a tool for facilitating ciliate detection using a simple agarose gel electrophoresis is to produce PCR amplicons with different sizes among the three species. Hence, the primer3plus algorithm was set to produce PCR amplicon with sizes of $400 \mathrm{bp}$ for Euplotes, $250 \mathrm{bp}$ for Coleps, and $180 \mathrm{bp}$ for Halteria.

Upon arrival, the primers were applied in a PCR program for each species, using a direct PCR and the same samples stored separately in the $-20^{\circ} \mathrm{C}$ deep freezer. PCR protocol and conditions followed the same as mentioned in section 2.3. herein, but using a gradient of annealing temperatures between $50-60^{\circ} \mathrm{C}$ to detect the best for each organism. The PCR products were resolved in $1 \%$ agarose gel stained with 0.5 $\mu \mathrm{g}$ ethidium bromide and visualized using a UV transilluminator.

Later on, field water collected and counted for the target organisms. From a 10 mL sample containing 2,450 Euplotes, 4,800 Coleps, and 8,050 Halteria individuals; $1 \mathrm{~mL}$ in triplicates was placed in a $1.5 \mathrm{~mL}$ sterile Eppendorf tubes, then used to make 3 half-serial dilutions with deionized water. All tubes were centrifuged at $12,000 \mathrm{~g}$ for $10 \mathrm{~min}$ and the supernatant was completely removed. $250 \mu \mathrm{L}$ of $5 \%$ Chelex ${ }^{\circledR} 100$ sodium form resin (Sigma-Aldrich, Madrid, Spain) in TE buffer ( $\mathrm{pH} 8$ ) were added to the precipitate, together with $2.4 \mathrm{U}$ of Proteinase $\mathrm{K}$ solution (Thermo Scientific Cat. No. E00491). The samples were incubated at $55^{\circ} \mathrm{C}$ for $90 \mathrm{~min}$, then at $100{ }^{\circ} \mathrm{C}$ for 20 min. DNA samples were then stored in a $4{ }^{\circ} \mathrm{C}$ fridge and PCR amplifications were done in a period not exceeding 1 week. The rest was stored at $-20^{\circ} \mathrm{C}$ for archival storage. A final PCR was carried out to quantify the intensity of each organism in relation to its count in the serially diluted samples, using the same PCR program and protocol mentioned in section 2.3 herein, but applying only 25 PCR cycles instead 40, and using the annealing temperatures adequate for each species-specific primer pair. PCR amplicons were resolved in a $1 \%$ agarose gel stained with $0.5 \mu$ g ethidium bromide. Band intensities were quantified using ImageJ software. Finally, the regression coefficient $\left(\mathrm{r}^{2}\right)$ was calculated for each organism's dilutions vs. intensity of PCR bands to assess the robustness of quantitative detection by PCR. Finally, the PCR amplicons produced for each sepcies from the highest concentration samples were sequenced to confirm the identity of the amplified products. 


\section{Statistical analysis}

For all measurements, the results were analyzed using one-way ANOVA in the program Statgraphics Centurion IX. Least significant Difference (LSD) was used as a post-hoc test to estimate statistical significance among band intensities in different serial dilutions for each organism. Differences were considered significant at $\mathrm{P}<0.01$.

\section{RESULTS}

\section{PCR amplification for 18s ribosomal RNA gene.}

18srDNA universal ciliate primers (EupF- EupR) were designed for ciliates. Sequences and PCR protocol for these primers are shown in Table 1. The gene coding for $18 \mathrm{srDNA}$ could be successfully amplified, showing the expected $800 \mathrm{bp}$-bands for the three tested organisms (Figure 1).

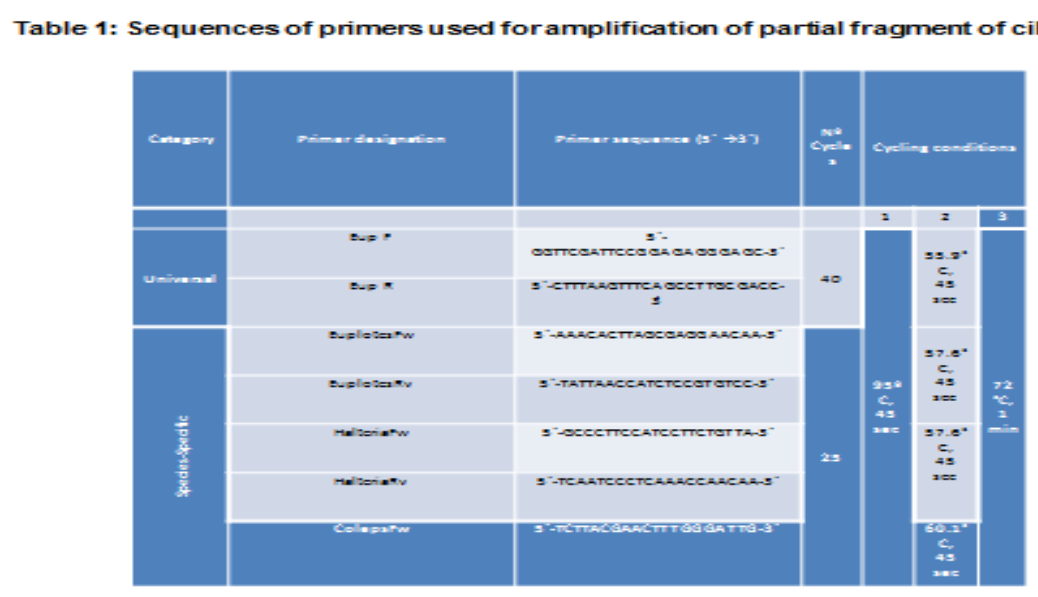

Figure 1. Agarose gel (1\%) electrophoresis showing a 800 bp fragment of the 18srDNA of (a) Coleps, (b) Halteria, and (c) Euplotes. Sizes of ladder bands are shown in base pairs (bp) beside each band.

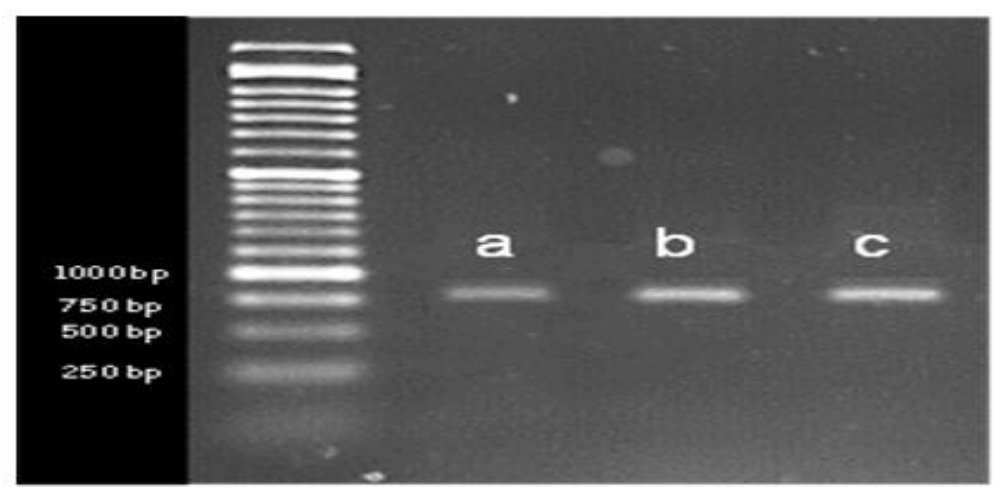

Sequencing resulted in excellent quality sequence chromatograms, indicating the efficiency of the direct PCR applied for amplification of the 18srDNA of each organism. Manual trimming of the sequences for removal of initial low quality sequences resulted in about 750 base pairs-long sequences that exhibited 99-100\% identities with E. woodruffi and E. parawoodruffi for the Euplotes samples (accession numbers JQ801446 and FJ998025), H. grandinella for Halteria samples (acc. No. MF002420, MF002421), and 99.42\% with C. hirtus for Coleps samples (acc. No. AM292311.1). River Nile samples of Euplotes, Coleps, and Halteria with the accession numbers MN535693, MN535694, MN535695, respectively. 
Maximum likelihood phylogenetic tree (Figure 2) coincided with the results of BLAST comparison. It exhibited a clear clustering of Mansoura's Nile samples with their counterparts whose 18srDNA sequences were previously obtained and deposited in the GenBank database. Taking Paramecium species as an outgroup, three clusters could be clearly identified with a high bootstrap support values, in which each one of Nile species fitted perfectly. The first one encompassed Euplotes species coming from freshwater and brackish water bodies in Egypt, the country where current study was carried out, China, USA, Germany, Italy, Denmark, Korea, and Colombia.

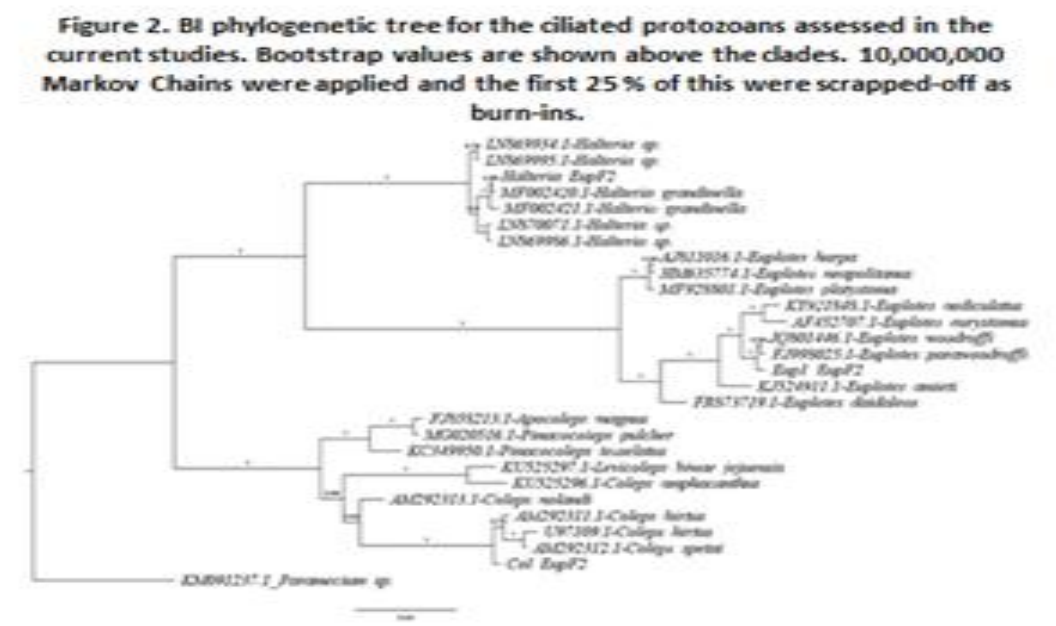

The second one encompassed Halteria samples from Egypt, China, Korea, and UK. The third one included different Coleps species from Egypt, China, Korea, and Germany. Unfortunately, No 18srDNA sequences for Mansoura's Nile ciliates were available in the GenBank database for the Middle East region, hence no clear phylogenetic relation among these species and their relatives in the nearby geographical regions could be deduced.

Species-specific primers designed and used for targeted identification of Nile ciliates collected in the current study resulted in band sizes as expected and mentioned in section 2.3 (Figure 3). A annealing temperature of $57.6{ }^{\circ} \mathrm{C}$ for Euplotes and Halteria, but $60.1{ }^{\circ} \mathrm{C}$ for Coleps, were the best. Primers' sequences and PCR conditions are shown in Table 1. Serially diluting samples containing targeted ciliates resulted in a significant decrease in the amount of DNA available from each organism, as identified by the decreased PCR product intensity (Figure 4). PCR products' intensities and the number of ciliate cells from all studied species showed a highly positive and significant correlation $\left(\mathrm{r}^{2=} 0.99\right.$ for Halteria, 0.95 for Coleps, and 0.94 for Euplotes) as could be seen in Figure $(5 \mathrm{a}, \mathrm{b})$.

Figure 3. Agarose gel (1\%) electrophoresis showing the results of amplification of (a) Coleps (b) Halteria(c) Euplotes gene by the designed specific primers. Sizes of ladder bands are shown in bp beside each band.

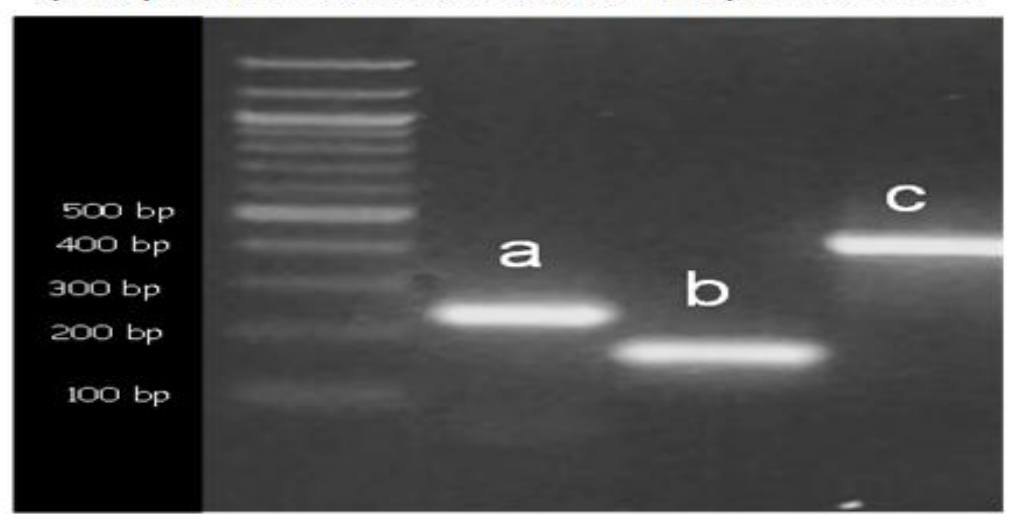


Figure 4: Agarose gel (1\%) electrophoresis showing the results of amplification of (a) Euplotes woodruffi, (b) Halteria grandinella and(c) Coleps hirtus 18srDNA by the designed specific primers after DNA extraction with descending half serial dilutions (left to right). Sizes of ladder bands are shown in bp beside each band.

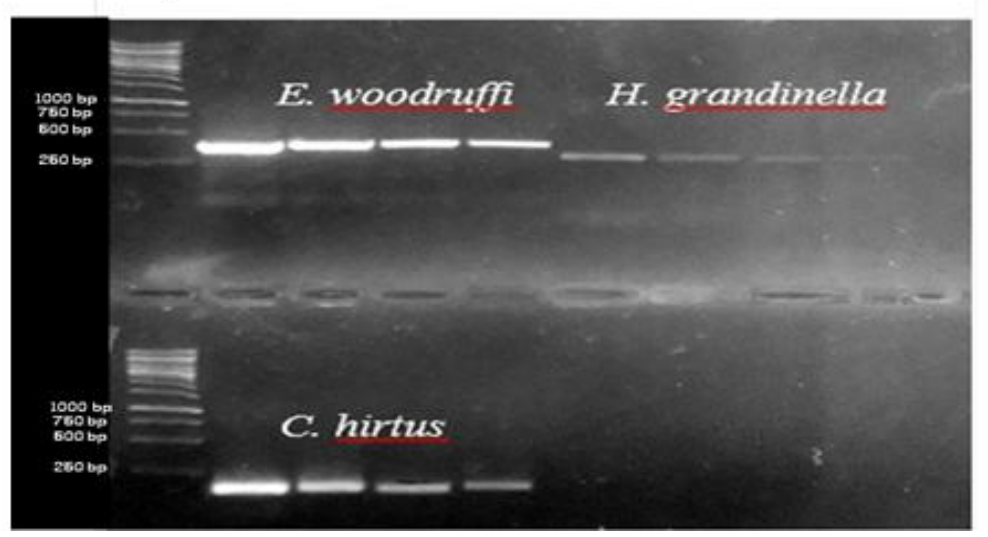

Figure 5: PCR products concentrations in relation to the number of ciliates' in water (Fig. 5a) and regression coefficient for all the three species (Fig. 5b).

Small letters in Fig. 5 a refer to significant difference among the serial dilutions of the each organism ( $\mathrm{P} \times 0.01)$.
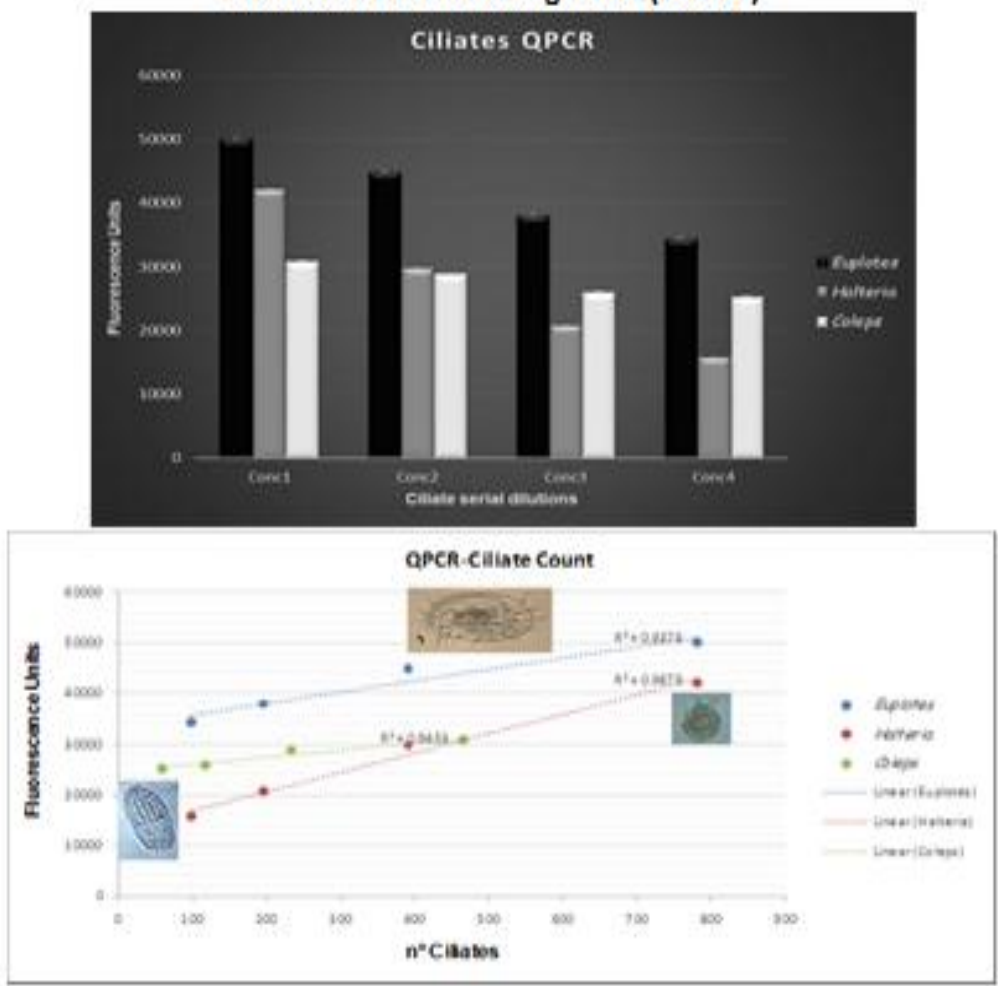

Finally, the sequenced QPCR amplicons were $100 \%$ identical to those obtained by sequencing the results of the direct PCR over the single-cell using the speciesspecific 18 srDNA primers.

\section{DISCUSSION}

For the best of authors" knowledge, the current study is the first trial in River Nile to apply molecular genetic approaches for identifying and assessing the 
abundance of free living freshwater ciliates. The newly designed 18srDNA primers could be efficiently applied in a direct PCR to barcode different ciliate species. Moreover, the species.-specific 18srDNA primers exhibited a clear quantitative capacity. The highly significant, positive correlation between organism count and PCR profiles for the three assessed ciliate specie indicate the efficiency of these primers to detect changes in Euplotes, Halteria, and Coleps abundances in a given freshwater body, especially since the serial dilutions were made from the Nile water that contained other plankton species. The sequencing step appended to the QPCR measurement confirmed the high specificity of the species-specific designed primers.

Furthermore, the investigated species in the Mansoura Nile herein showed very high sequence identity with fresh- and brackish water representatives from different areas in the world. The Euplotes species present in our samples showed the closest sequence identity and phylogenetic relation with Euplotes woodruffi and Euplotes parawoodruffi. Identification of Euplotes species using only morphological approaches is not completely accurate. Application of 18srDNA seqeuecning has been proven, even with very slight sequence differences, to be adequate for characterization of different morphotypes of the same species, as well as to characterize cryptic species in the world of euplotid ciliates (Fotedar et al., 2016; Yan et al., 2018). For example, E. woodruffi was originally isolated from a freshwater pond in China (Gaw 1939) and subsequently found in fresh- and brackish water habitats in Asia, Europe, North America, and Africa (e.g. Fokin et al., 2008; Gaw, 1939; Pierson, 1943; Vannini et al., 2012). It is a common model organism in many fields of protistology (e.g., Song and Bradbury, 1997; Fokin et al., 2008). E. parawoodruffi was originally isolated from brackish waters in the USA (Song and Bradbury 1997). E. parawoodruffi is separated from $E$. woodruffi by several morphological differences in body shape, pre-oral pouch, adoral zone of membranelles, macronucleus arm length, ciliary pattern and silver line system, and in particular the habitat (Song and Bradbury, 1997). However, since short time, Schwarz et al., (2007) referred to molecular data for E. woodruffi and E. parawoodruffi that cast doubt on the separation of the two species from each other. Dai, et al., (2013) isolated E. parawoodruffi and E. woodruffi from brackish waters and referred to $E$. parawoodruffi as a junior synonym for $E$. woodruffi. The $99 \%$ sequence identity between the Mansoura's Nile species and both E. woodruffi and E. parawoodruffi indicated that our species is then E. woodruffi. Another example but for characterization of cryptic species of the genus Euplotes is the case of E. estuarinus and E. curdsi. They are very close together in morphology and ciliary pattern but differ in the sequence of the 18srDNA by only by $1 \mathrm{bp}$. Likewise, E. harpa and E. neapolitanus are also morphologically similar but differ in only by 3 - 4 bp in their 18srDNA sequences (Yan. et al., 2018).

Besides being an active predator for smaller planktonic organisms, bacteria, and algae (Tarangkoon et al., 2018), Euplotes capability to tolerate heavy metals concentrations seems considerable. Rehman et al., (2009) isolated E. mutabilis from industrial wastewater, where it survived $\mathrm{Zn}$ levels up to $33 \mathrm{mg} \mathrm{L}^{-1}, \mathrm{Cd}$ up to $22 \mathrm{mg} \mathrm{L}^{-1}$ and $\mathrm{Ni}$ up to $18 \mathrm{mg} \mathrm{L}^{-1}$. It was suggestd as a possible bioremidation agent as it has absorption ability to $85 \% \mathrm{Zn}, 84 \%$ of $\mathrm{Cd}$ and $87 \%$ of Ni after $96 \mathrm{~h}$ (Rehman et al., 2009). Similarly, E. crassus was suggested as a fundamental biomarker organism for monitoring the effects of heavy metals, as it could tolerate $\mathrm{Cu}$ level of $1.58 \mathrm{mg} \mathrm{L}^{-1}, \mathrm{~Pb}$ level of $4.13 \mathrm{mg} \mathrm{L}^{-1}$, and $\mathrm{Zn}$ level of $4.97 \mathrm{mg} \mathrm{L}^{-1}$; after $48 \mathrm{~h}$ exposure (Kim, et al., 2011).

Coleps obtained in the current study from river Nile showed $99 \%$ COI sequence identity with $C$. hirtus. Coleps is a widely distributed genus present in many habitats 
as fresh-, brackish and saline waters, being distributed in both benthos and plankton (Dragesco and Dragesco-Kerneis, 1991; Foissner 1980, 1984). Its usual feeds include bacteria, algae, flagellates and living or dead plant and animal tissue (Foissner et al., 1999; Mazanec and Trevarrow, 1998). Such like Euplotes, the advent of DNA barcoding aided much the taxonomy of this genus and the allied ones. Phylogenetic analyses of different colepidae species exhibited that Coleps amphacanthus is closer to the clade encompassing Levicoleps spp., especially L. biwae jejuensis than to the other clade encompassing all other Coleps spp. (Lu et al., 2016). Similarly, 18srDNA based phylogeneies exhibited the sister relationships between genera Apocoleps and Pinacocoleps (Moon et al., 2017). Hence, still many aspects of taxonomy in that group are in need for more research.

The obtained Mansoura's Nile Halteria species showed $100 \%$ sequence identity with $H$. grandinella (Müller, 1786). The collected sample was closer to the ones isolated from China and UK freshwater ponds (Riley et al., 2001; Wang et al., 2017). In general this species is a cosmopolitan one, being found in most freshwater environments all over the world (Finlay, 2002). It feeds on bacteria, nanoprotists, algae and detritus (Jürgens et al., 2000). However, and in contrast to the two previously assessed species in the current study, it needs variety of food because it cannot be feed on a pure bacterial diet. Another key criterion in H. grandinella is that it exhibits the highest record for rDNA copy number in ciliates, being about 567,893 per cell, regardless to the cell or genome size (Wang et al., 2017).

\section{CONCLUSION}

Direct PCR over individual freshwater ciliates was proven to be very efficient tool for molecular investigations of these uni-cellular organisms. Application of DNA barcoding in investigating the free living ciliates seem to be fundamental to identify, assess and control the presence and abundance of these organisms. Specially, since they represent a cornerstone for lower and higher organisms' biodiversity, water treatment and heavy metals bioremidiation processes, and consequently, the ecosystem health and performance in general.

\section{REFERENCES}

Abraham, J. S.; Sripoorna, S.; Choudhary, A.; Toteja, R.; Gupta. R .; Makhija, S. and Warren, A. (2017). Assessment of heavy metal toxicity in four species of freshwater ciliates (Spirotrichea: Ciliophora) from Delhi, India. Curr. Sci., 113 $(11,10):$ 2141-2150.

Abraham, J. S.; Sripoorna, S.; Dagar, J.; Jangra, S.; Kumar, A.; Yadav, K.; Singh, S.; Goyal, A.; Maurya, S.; Gambhir, G.; Toteja, R.; Gupta, R.; Singh, D. K.; ElSerehy, H.A.; Al-Misned, F.A.; Al-Farraj, S. A.; Al-Rasheid, K. A.; Maodaa, S. A. and Makhija, S. (2019). Soil ciliates of the Indian Delhi Region: Their community characteristics with emphasison their ecological implications as sensitive bio-indicators for soil quality. Saudi. J. Biol. Sci., 04- 013. Https: //doi.org/ 10.1016/j.sjbs.

Alekperov, I.; Buskey, E. and Snegovaya, N. (2006). New and little known free-living ciliates from the plankton of the Caspian Sea. Protistol., 4(3): 195-201.

Altschul, S. F.; Gish, W.; Miller, W.; Myers, E.W.; and Lipma, D.J. (1990). Basic local alignment search tool. Mol. Biol., 215(3):403- 410. 
Catalani, E.; Serafini, F. P.; Zecchini, S.; Picchietti, S.; Fausto, A. M.; Marcantoni, E.; Buonanno, F.; Ortenzi, C.; Perrotta, C.; and Cervia, D.(2016). Natural products from aquatic eukaryotic microorganisms for cancer therapy: Perspectives on anti-tumor properties of ciliate bioactive molecules. Pharmacol. Res., 113(A): 409-420.

Chen, X. R.; Zhao, Y.; Al-Farraj, S.A.; Al-Quraishy, S.A.; El-Serehy, H. A.; Shao, C. and Al-Rasheid, K. A. S. (2013). Taxonomic descriptions of two marine ciliates, Euplotes dammamensis n. sp. And Euplotes balteatus (Dujardin, 1841) Kahl, 1932 (CiliophoraSpirotrichea, Euplotida), collected from the Arabian Gulf, Saudi Arabia. Acta Protozool., 52: 73-89.

Corliss, J. O. (2002). Biodiversity and biocomplexity of the protists and an overview of their significant roles in maintenance of our biosphere. Acta .Protozool., 41(3): 199-220.

Curds, C.R. (1975). A guide to the species of the genus Euplotes (Hypotrichida, Ciliatea). Bull. Br. Mus. Nat. Hist. J. Zool., 28:1-61.

Dai, R., Xu, K. and He, Y. (2013). Morphological, physiological, and molecular evidences suggest that Euplotes parawoodruffi is a junior synonym of Euplotes woodruffi (Ciliophora, Euplotida). J. Eukaryot. Microbiol., 60: 70-78.

Debastiani, C.; Meira, B. R.; Lansac-Tôha, F. M.; Velho, L. F. M. and Lansac-Tôha, F. A. (2016). Protozoa ciliates community structure in urban streams and their environmental use as indicators. Braz. J. Biol., 76 (4): 1043-1053.

Dragesco, J. and Dragesco-Kerneis, A. (1991). Free-living ciliates from the coastal area of Lake Tanganyika (Africa). Eur. J. Protistol., 26: 216-235.

Finlay, B. J. (2002). Global dispersal of free-living microbial eukaryote species. Science., 296: 1061-1063.

Foissner, W. (1980). Taxonomische Studien über die Ciliaten des Großglocknergebietes (Hohe Tauern, Österreich): I. Familien Holophryidae, Prorodontidae, Plagiocampidae, Colepidae, Enchelyidae und Lacrymariidae nov. fam. Annalen des Naturhistorischen Museums in Wien. Serie B für Botanik und Zoologie, 49-85.

Foissner, W. (1984). Infraciliatur, Silberliniensystem und Biometrie einiger neuer und wenig bekannter terrestrischer, limnischer und mariner Ciliaten (Protozoa: Ciliophora) aus den Klassen Kinetofragminophora, Colpodea und Polyhymenophora. Stapfia, 12: 1-165.

Foissner, W.; Berger, H. and Scaumburg, J. (1999). Identification and Ecology of Limnetic Plankton Ciliates. Bayerisches Landesamt fur Wasserwirtschaft, Munchen. 272-287.

Fokin, S. I.; Di Giuseppe, G.; Erra, F. and Dini, F. (2008). Euplotespora binucleata n. gen., n. sp. (Protozoa: Microsporidia), a parasite infecting the hypotrichous ciliate Euplotes woodruffi, with observations on microsporidian infections in Ciliophora. J. Eukaryot. Microbiol., 55: 214-228.

Forster, D.; Filker, S.; Kochems, R.; Breiner, H.; Cordier, T.; Pawlowski, J. and Stoeck, T. (2019). A Comparison of Different Ciliate Metabarcode Genes as Bioindicators for Environmental Impact Assessments of Salmon Aquaculture. J. Eukaryot. Microbiol., 66: 294-308.

Fotedar, R.; Stoeck, T.; Filker, S.; Fell, J.W.; Agatha, S.; Al Marri, M. and Jiang, J. (2016). Description of the halophile Euplotes qatarensis nov. spec. (Ciliophora, Spirotrichea, Euplotida) isolated from the hypersaline Khor Al-Adaid Lagoon in Qatar. J. Eukaryot. Microbiol., 63: 578-590. 
Galal, M. (2013). Protozoan diversity in the activated sludge at Benha waste-water treatment plant, Kalubeyia province, Egypt. J. Int. Dev., 2(1): 13-20.

Galal, M.; Authman, M.N., and Gaber, N. (2011). Ciliated protozoan diversity at ElHammra hypersaline lake, Wadi Al-Natron Egypt. Afr. J. Biol. Sci., 7 (2): 1-12.

Gaw, Z. H. (1939). Euplotes woodruffi sp. nov. Arch. Protistenk, 93: 1-5.

Grimonprez, A.; Molza, A.; Laurent, M. C.Z.; Jean-Louis Mansot, J L. and Gros. O. (2018). Thioautotrophic ectosymbiosis in Pseudovorticella sp., a peritrich ciliate species colonizing wood falls in marine mangrove. Europ. J. Protistol ., 62: 4355. 10.1016/j.ejop.2017.11.002. hal-01655933.

Grothjan, J.J. and Young. E. B. (2019). Diverse microbial communities hosted by the model carnivorous pitcher plant Sarracenia purpurea: analysis of both bacterial and eukaryotic composition across distinct host plant populations. Peer. J. Life Enviroment, 7: 6392.

Gutiérrez, J. C.; Martín-González, A.; Díaz, S.; Amaro, F.; Ortega, R.; Gallego, A. and de Lucas, M. P. (2008). Ciliates as cellular tools to study the eukaryotic cell: heavy metal interactions. In Heavy Metal Pollution (eds Brown, S. E. and Welton, W. C.), Nova Science Publishers, New York, 1-44.

Jürgens, K. and Šimek K. (2000). Functional response and particle size selection of Halteria cf. grandinella, a common freshwater oligotrichous ciliate. Aquat. Microb . Ecol., 22: 57-68.

Kahl, A. (1932). Urtiere order Protozoa I: Wimpertiere order Ciliata (Infusoria) 3. Spirotricha. Tierwelt Dtschl. 25: 399-650.

Kim, S. H.; Jung, M. Y. and Lee, Y. M. (2011). Effect of heavy metals on the antioxidant enzymes in the marine ciliate Euplotes crassus. Toxicol. Environ. Health. Sci ., 3(4): 213-219.

Lu B., Ma. M.; Gao, F.; Shi, Y. and Chen, X. (2016). Morphology and molecular phylogeny of two colepid species from China, Coleps amphacanthus Ehrenberg, 1833 and Levicoleps biwae jejuensis Chen et al., (2016) (Ciliophora, Prostomatida). Zool. Res., 37:176-185.

Madoni, P. and Romeo, M. G. (2006). Acute toxicity of heavy metals towards freshwater ciliated protists. Environ. Pollut., 141: 1-7.

Mazanec, A. and Trevarrow, B. (1998). Coleps, Scourge of the Baby Zebrafish. Zebrafish. Sci. Mon., 5-1.

Moon, J. H.; Kim, J. H. and Jung, J .H. (2017). Taxonomical reinvestigation of the colepid species Pinacocoleps pulcher(Spiegel, 1926) Foissner et al., 2008 (Ciliophora: Prorodontida: Colepidae). Acta Protozool., 56: 161-169.

Müller, O.F. (1786). Animalcula Infusoria Fluviatilia et Marina, quaeDetexit Systematice Descripsit et ad Vivum Delineari Curavit. Nicolai Mölleri, Hauniae.

Patterson, D.J. and Hedley, S. (1992). Free-living freshwater protozoa. A colour guide. Wolfe publishing Ltd. England.

Pierson, B. F. (1943). A comparative morphological study of several species of Euplotes closely related to Euplotes patella. J. Morphology, 72:125-165.

Pitsch, G.; Bruni, E. P.; Forster, D.; Qu, Z.; Sonntag, B.; Stoeck ,T. and Posch, T. (2019). Seasonality of Planktonic Freshwater Ciliates: Are Analyses Based on V9 Regions of the 18S rRNA Gene Correlated With Morphospecies Counts? Front. Microbiol. https://doi.org/10.3389/fmicb.2019.00248

Pudpong, S. and Chantangsi, C. (2015). Effects of four heavy metals on cell morphology and survival rate of the ciliate Bresslauides sp. Trop. Nat. Hist., 15:117-125. 
Radhakrishnan, R. and Jayaprakas, V. (2015). Free living protozoans as bioindicators in Vembanad Lake, Kerala, India, an important Ramsar site. Int. J. Fish. Aquat. Stud., 2(3): 192-197.

Rambaut, A.; Drummond, A.J.; Xie, D.; Baele, G. and Suchard, M. A. (2018). Posterior Summarization in Bayesian Phylogenetics Using Tracer 1.7. Syst. Biol., 67(5): 901-904.

Rehman, A.; Shakoori, F. R. and Shakoori, A. R. (2009). Heavy Metal Uptake by Euplotes mutabilis and its Possible Use in bioremediation of Industrial Wastewater. Bull. Environ. Contam. Toxicol., 83: 130-135.

Riley, L.J. and Katz, L.A. (2001). Widespread Distribution of Extensive Chromosomal Fragmentation in Ciliates. Mol. Biol. Evol., 18(7): 1372-1377.

Ronquist, F.; Nylander, J.A.A.; Vårdal, H. and Nieves-Aldrey, J. L. (2018). Life history of Parnips and the evolutionary origin of gall wasps. J. Hymenopt. Res., 65: 91-110. https://doi.org/10.3897/jhr.65.24115

Schwarz, M.V.J.; Zuendorf, A. and Stoeck, T. (2007). Morphology, ultrastructure, molecular phylogeny, and autecology of Euplotes elegans Kahl, 1932 (Hypotrichida; Euplotidae) isolated from the anoxic Mariager Fjord, Denmark. J. Eukaryot. Microbiol., 54: 125-136.

Schwarz, M.V.J. and Stoeck, T. (2007). Euplotes pseudoelegans n.sp. (Hypotrichida; Euplotidae): description of a new speciespreviously misidentified as Eplotes elegans Kahl, 1932. Acta Protozool., 46: 193-200.

Somasundaram, S.; Abraham, J. S.; Maurya, S.; Makhija, S.; Gupta, R. and Toteja, R. (2018). Cellular and molecular basis of heavy metal -induced stress in ciliates. Curr. Sci., 114: 1858-1865.

Song, W. and Bradbury, P. C. (1997). Comparative studies on a new brackish water Euplotes, E. parawoodruffi n. sp., and a redescription of Euplotes woodruffi Gaw, 1939 (Ciliophora; Hypotrichida). Arch. Protistenk., 148: 399-412.

Syberg-Olsen, M. J.; Irwin, N.A.T.; Vannini, C.; Erra, F.; DiGiuseppe, G., Boscaro, V. and Keeling, P.J. (2016). Biogeography and character evolution of the ciliate genus Euplotes (Spirotrichea,Euplotia), with description of Euplotes curdsi sp. nov. PLoS ONE, 11(11), e0165442. doi:10.1371/journal.pone.0165442

Tamura, K.; Stecher, G.; Peterson, D.; Filipski, A. and Kumar, S. (2013). MEGA6: Molecular Evolutionary Genetics Analysis version 6.0. Mol. Biol. Evol., 30: 2725-2729

Tarangkoon, W.; Mahae, N. and Tanyaros, S., (2018). The Effect of Different Feed Types on the Growth Rate and Biochemical Composition of the Marine ciliate, Euplotes sp. J. Fish. Environ. 42 (1): 24-32.

Thompson, J. D.; Higgins, D.G. and Gibson, T.J. (1994). Clustal W: improving the sensitivity of progressive multiple sequence alignment through sequence weighting, position-specific gap penalties and weight matrix choice. Nucleic Acids Res., 22 (22): 4673-4680.

Toteja, R.; Makhija, S.; Sripoorna, S.; Abraham, J. S. and Gupta, R. (2017). Influence of copper and cadmium toxicity on antioxidant enzyme activity in freshwater ciliates. Indian J. Exp. Biol., 55: 694-701.

Vannini, C.; Ferrantini, F.; Ristori, A.; Verni, F. and Petroni, G. (2012). Beta proteobacterial symbionts of the ciliate Euplotes: origin and tangled evolutionary path of an obligate microbial association. Environ. Microbiol., 14: 2553-2563.

Walczyńska, A.; Sobczyk, M.; Fiałkowska, E.; Pajdak-Stós, A.; Fyda, J. and Wiąckowski, K. (2018). Interaction between a bacterivorous ciliate Aspidisca 
cicada and a Rotifer Lecane inermis: Doozers and Fraggles in Aquatic Flocs. Microb. Ecol., 75: 569-581.

Wang, C.; Zhang, T.; Wang, Y.; Katz, L. A.; Gao, F. and Song, W. (2017). Disentangling sources of variation in SSU rDNA sequences from single cell analyses of ciliates: impact of copy number variation and experimental error. Proc. R. Soc., B (284): 2017-0425.

Yan, Y.; Fan, Y.; Luo, X.; El-Serehy, H. A.; Bourland, W. and Chen, X. (2018). New contribution to the species-rich genus Euplotes: morphology, ontogeny and systematic position of two species (Ciliophora; Euplotia). Eur. J. Protistol., 64:20-39.

Zhao, Y.; Yi, Z.; Warren, A., and Song, W. (2018). Species delimitation fro the molecular taxonomy and ecology of the widely distributed microbial eukaryote genus Euplotes (Alveolata, Cil-iophora). Proc. R. Soc., B (285): 2017-2159.

\section{ARABIC SUMMARY}

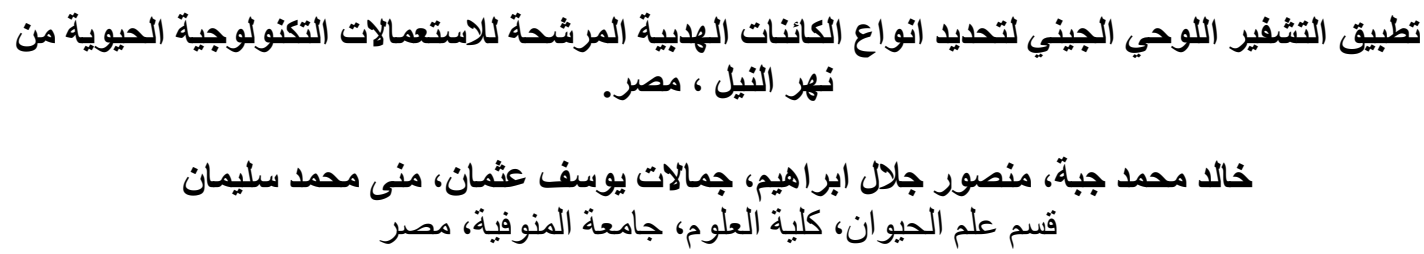

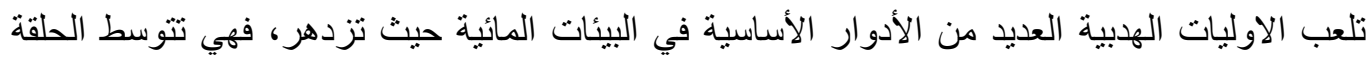

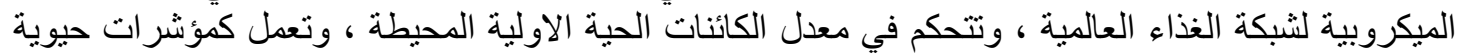

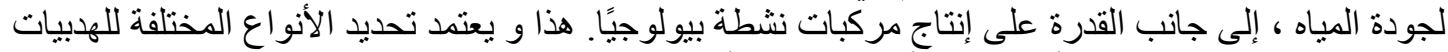

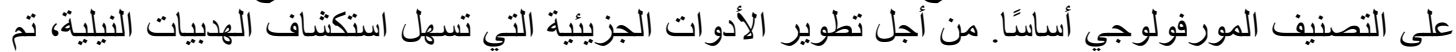

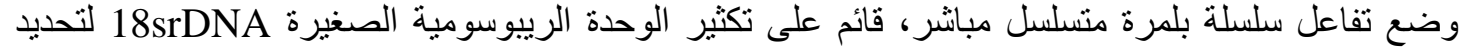

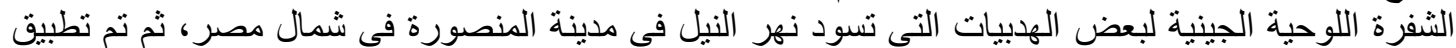

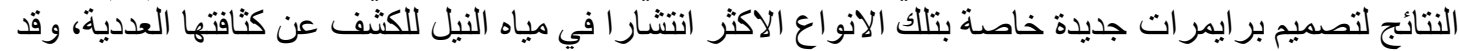

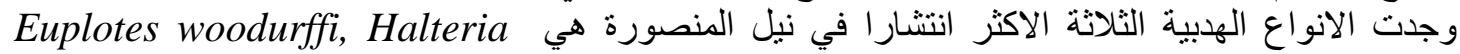
لو و ونتج عن البر ايمر ات الخاصة بتلك الانواع تفاعلات التات بلمرة منسلسلة بكفاءة

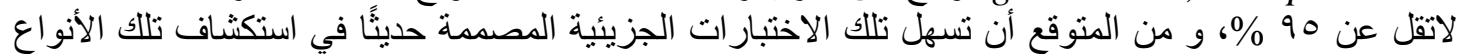
وقياسها في المو ائل المائية المختلفة حيثما وجدت الزئ ، مما يضيف مساهمة كبيرة في الجهود المستقبلية لاستغلالها كموارد للتكنولوجيا الحيوية الزرقاء. 